\title{
Front Matter: Volume 6990
}

, "Front Matter: Volume 6990," Proc. SPIE 6990, Photonic Crystal Fibers II, 699001 (12 May 2008); doi: 10.1117/12.801849

SPIE. Event: SPIE Photonics Europe, 2008, Strasbourg, France 


\title{
PROCEEDINGS OF SPIE
}

\section{Photonic Crystal Fibers II}

\author{
Kyriacos Kalli \\ Waclaw Urbanczyk \\ Editors \\ 9-10 April 2008 \\ Strasbourg, France \\ Sponsored by \\ SPIE Europe \\ Cosponsored by \\ Alsace International (France) \\ Conseil Général du Bas-Rhin (France) \\ Région Alsace (France) \\ Communauté Urbaine de Strasbourg (France) \\ Cooperating Organizations \\ AFOP_Association Française des Industries de l'Optique et de la Photonique (France) \\ EOS-European Optical Society (Germany) - EPIC-European Photonics Industry Consortium \\ (France) • ePIXnet (Belgium) • IOP_Institute of Physics (United Kingdom) • NEMO—Network of \\ Excellence on Micro-Optics (Belgium) • OLAS (Italy) • The OLLA Project (Germany) • OPERA 2015 \\ (Belgium) • PhOREMOST (Ireland) • Photonics Knowledge Transfer Network (United Kingdom) \\ Photonics Cluster (United Kingdom) • Photonics4Life (Germany) • Photonics 21 (Germany) \\ RhenaPhotonics Alsace (France) \\ Published by \\ SPIE
}

Volume 6990

Proceedings of SPIE, 0277-786X, v. 6990 
The papers included in this volume were part of the technical conference cited on the cover and title page. Papers were selected and subject to review by the editors and conference program committee. Some conference presentations may not be available for publication. The papers published in these proceedings reflect the work and thoughts of the authors and are published herein as submitted. The publisher is not responsible for the validity of the information or for any outcomes resulting from reliance thereon.

Please use the following format to cite material from this book:

Author(s), "Title of Paper," in Photonic Crystal Fibers II, edited by Kyriacos Kalli, Waclaw Urbanczyk, Proceedings of SPIE Vol. 6990 (SPIE, Bellingham, WA, 2008) Article CID Number.

ISSN 0277-786X

ISBN 9780819471888

Published by

SPIE

P.O. Box 10, Bellingham, Washington 98227-0010 USA

Telephone +1 3606763290 (Pacific Time) · Fax +1 3606471445

SPIE.org

Copyright () 2008, Society of Photo-Optical Instrumentation Engineers

Copying of material in this book for internal or personal use, or for the internal or personal use of specific clients, beyond the fair use provisions granted by the U.S. Copyright Law is authorized by SPIE subject to payment of copying fees. The Transactional Reporting Service base fee for this volume is $\$ 18.00$ per article (or portion thereof), which should be paid directly to the Copyright Clearance Center (CCC), 222 Rosewood Drive, Danvers, MA 01923. Payment may also be made electronically through CCC Online at copyright.com. Other copying for republication, resale, advertising or promotion, or any form of systematic or multiple reproduction of any material in this book is prohibited except with permission in writing from the publisher. The CCC fee code is 0277-786X/08/\$18.00.

Printed in the United States of America.

Publication of record for individual papers is online in the SPIE Digital Library.

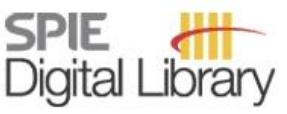

SPIEDigitalLibrary.org

Paper Numbering: Proceedings of SPIE follow an e-First publication model, with papers published first online and then in print and on CD-ROM. Papers are published as they are submitted and meet publication criteria. A unique, consistent, permanent citation identifier (CID) number is assigned to each article at the time of the first publication. Utilization of CIDs allows articles to be fully citable as soon they are published online, and connects the same identifier to all online, print, and electronic versions of the publication. SPIE uses a six-digit CID article numbering system in which:

- The first four digits correspond to the SPIE volume number.

- The last two digits indicate publication order within the volume using a Base 36 numbering system employing both numerals and letters. These two-number sets start with 00, 01, 02, 03, 04, 05 , $06,07,08,09,0 A, 0 B \ldots 0 Z$, followed by 10-1Z, 20-2Z, etc.

The CID number appears on each page of the manuscript. The complete citation is used on the first page, and an abbreviated version on subsequent pages. Numbers in the index correspond to the last two digits of the six-digit CID number. 


\section{Contents}

vii Conference Committee

SESSION 1 THE NEXTGENPCF PROJECT: ADVANCES IN FUNDAMENTALS

699002 European Union R\&D Next Generation Photonic Crystal Fibres project [6990-01]

P. Sansonetti, L. Gasca, P. Nouchi, Draka (France)

699003 Fabrication and characterization of germanium-doped highly non-linear photonic crystal fibres [6990-02]

G. Mélin, S. Lempereur, A. Fleureau, L. Galkovsky, S. Richard, H. Maerten, E. Burov,

P. Nouchi, Draka (France)

699004 Control of surface modes in hollow-core bandgap fibers [6990-03]

R. Amezcua-Correa, S. G. Leon-Saval, F. Gérôme, T. Birks, J. Knight, Univ. of Bath (United Kingdom)

699005 Multicomponent glass microstructured fibers for nonlinear applications [6990-04]

J. Kobelke, K. Schuster, S. Grimm, D. Litzkendorf, J. Kirchhof, A. Schwuchow, H. Bartelt, Institute of Photonic Technology Jena (Germany); A. Gebhardt, VITRON Spezialwerkstoffe GmbH (Germany)

\section{SESSION 2 THE NEXTGENPCF PROJECT: USES AND APPLICATIONS}

699007 Methods for visible supercontinuum generation in doped/undoped holey fibres [6990-06] P. Leproux, C. Buy-Lesvigne, V. Tombelaine, V. Couderc, J. L. Auguste, J. M. Blondy, XLIM (France); G. Mélin, Draka (France); K. Schuster, J. Kobelke, H. Bartelt, IPHT Jena (Germany)

699008 Lumped Raman fiber amplifiers based on highly non-linear photonic crystal fiber [6990-07] D. Menashe, RED-C Optical Networks (Israel); D. Bayart, S. Borne, Alcatel-Lucent (France)

699009 Dynamics and spectral properties of a grating-free Raman laser made with a highly nonlinear photonic crystal fiber [6990-08]

S. Randoux, N. Y. Joly, Univ. des Sciences et Technologies de Lille (France); G. Mélin, A. Fleureau, L. Galkovsky, S. Lempereur, Draka (France); P. Suret, Univ. des Sciences et Technologies de Lille (France)

\section{SESSION 3 JOINT SESSION: SENSING APPLICATIONS OF PCF}

6990 OA Oxygen sensor based on hollow-core photonic crystal fibres [6990-09]

M. Cabaleiro, V. Lange, D. Kühlke, Furtwangen Univ. of Applied Sciences (Germany) 
6990 OC The fabrication and characterization of fiber Bragg gratings in highly birefringent photonic crystal fibers for sensing applications [6990-11]

T. Geernaert, T. Nasilowski, K. Chah, Vrije Univ. Brussel (Belgium); M. Becker, M. Rothhardt, Institute of Photonic Technology (Germany); M. Szpulak, J. Olszewski, Wroclaw Univ. of Technology (Poland); K. Poturaj, J. Wójcik, Maria Curie-Sklodowska Univ. (Poland);

W. Urbanczyk, Wroclaw Univ. of Technology (Poland); H. Terryn, Vrije Univ. Brussel (Belgium); H. Bartelt, Institute of Photonic Technology (Germany); F. Berghmans, H. Thienpont, Vrije Univ. Brussel (Belgium)

\section{SESSION 4 MODELLING AND NUMERICAL ANALYSIS OF PCF}

6990 OE Design of microstructured optical fibres made from highly nonlinear glasses for FWM-based telecom applications [6990-13]

J. Kanka, Institute of Photonics and Electronics AS CR (Czech Republic)

6990 OG Single-mode and single-polarization operation of photonic crystal fibres [6990-15]

K. Namassivayane, A. B. M. Rahman, K. T. V. Grattan, City Univ. London (United Kingdom)

\section{SESSION 5 CHARACTERISATION AND APPLICATIONS OF PCF}

$6990 \mathrm{OH}$ Inscription of Bragg reflectors in all-silica microstructured optical fibres using $248 \mathrm{~nm}$, picosecond, and femtosecond laser radiation (Invited Paper) [6990-16]

S. Pissadakis, M. Livitziis, G. Violakis, M. Konstantaki, Foundation for Research and Technology - Hellas (Greece)

6990 ol Characterisation of femtosecond laser inscribed long period gratings in photonic crystal fibre (Invited Paper) [6990-17]

T. Allsop, Aston Univ. (United Kingdom); K. Kalli, Cyprus Univ. of Technology (Cyprus):

K. Zhou, G. Smith, Y. Lai, M. Dubov, K. Sugden, D. Webb, I. Bennion, Aston Univ. (United

Kingdom); M. Komodromos, Frederick Research Ctr. (Cyprus)

6990 0J Group dispersion measurement of a holey fiber by white-light spectral interferometry [6990-18]

P. Hlubina, D. Ciprian, R. Chlebus, Technical Univ. Ostrava (Czech Republic)

6990 OK Investigations of bending loss oscillations in large mode area photonic crystal fibers [6990-19]

T. Martynkien, Wroclaw Univ. of Technology (Poland) and Vrije Univ. Brussel (Belgium);

J. Olszewski, W. Urbanczyk, Wroclaw Univ. of Technology (Poland); T. Nasilowski,

F. Berghmans, H. Thienpont, Vrije Univ. Brussel (Belgium)

$6990 \mathrm{OL}$ Temperature sensitivity of Bragg gratings in PMMA and TOPAS microstructured polymer optical fibres [6990-20]

D. J. Webb, Aston Univ. (United Kingdom); K. Kalli, Cyprus Univ. of Technology (Cyprus);

C. Zhang, Aston Univ. (United Kingdom); M. Komodromos, Frederick Research Ctr. (Cyprus);

A. Argyros, M. C. Large, The Univ. of Sydney (Australia); G. Emiliyanov, O. Bang, E. Kjaer,

Technical Univ. of Denmark (Denmark) 
6990 OM Ytterbium-doped fibre lasers with tailored all-solid microstructured cladding (Invited Paper) [6990-21]

S. Février, L. Lavoute, Xlim, CNRS (France); D. Gaponov, Xlim, CNRS (France) and Fiber Optics Research Ctr. (Russia); M. Devautour, P. Roy, R. Jamier, Xlim, CNRS (France);

K. Schüster, J. Kobelke, S. Grimm, Institute of Photonic Technology (Germany);

S. L. Semjonov, M. E. Likhachev, M. M. Bubnov, E. M. Dianov, Fiber Optics Research Ctr. (Russia); M. Yu. Yashkov, V. F. Khopin, M. Y. Salganskii, A. N. Guryanov, Institute of Chemistry of High Purity Substances (Russia)

6990 ON Second harmonic generation in Ge-doped silica holey fibres and supercontinuum generation [6990-22]

V. Tombelaine, C. Buy-Lesvigne, V. Couderc, P. Leproux, XLIM (France):

G. Mélin, Draka (France); K. Schuster, J. Kobelke, H. Bartelt, IPHT (Germany)

699000 Single-sided supercontinuum generation in a photonic crystal fiber by selective excitation of the third-order mode [6990-23]

R. Cherif, M. Zghal, Engineering School of Communication of Tunis (Tunisia); L. Tartara,

V. Degiorgio, Univ. di Pavia (Italy)

$6990 \mathrm{OP} \quad$ Back seeding of picosecond supercontinuum generation in photonic crystal fibres [6990-24]

P. M. Moselund, M. H. Frosz, Technical Univ. of Denmark (Denmark) and Koheras A/S (Denmark); C. L. Thomsen, Koheras A/S (Denmark); O. Bang, Technical Univ. of Denmark (Denmark)

\section{SESSION 7 NONLINEAR AND ACTIVE PCF II}

$6990 \mathrm{OR} \quad$ Solitonic spectral transformations in double core photonic crystal fiber [6990-26]

I. Bugar, International Laser Ctr. (Slovak Republic); I. V. Fedotov, A. B. Fedotov, M.V. Lomonosov Moscow State Univ. (Russia); J. Chlpik, D. Lorenc, International Laser Ctr. (Slovak Republic); R. Buczynski, Univ. of Warsaw (Poland); D. Pysz, Institute of Electronic Materials Technology (Poland); F. Uherek, International Laser Ctr. (Slovak Republic); A. M. Zheltikov, M.V. Lomonosov Moscow State Univ. (Russia)

6990 OS Broadband supercontinuum generation with photonic crystal fibers made of soft glass [6990-27]

R. Buczynski, Univ. of Warsaw (Poland); D. Pysz, I. Kujawa, Institute of Electronic Materials Technology (Poland); J. Korzeniowski, Univ. of Warsaw (Poland); T. Martynkien, Wroclaw Univ. of Technology (Poland); T. Nasilowski, F. Berghmans, H. Thienpont, Vrije Univ. Brussel (Belgium); R. Stepien, Institute of Electronic Materials Technology (Poland)

6990 OT Technology of suspended core microstructured optical fibers for evanesced wave and plasmon resonance optical fiber sensors [6990-28] J. Wojcik, P. Mergo, M. Makara, K. Poturaj, L. Czyżewska, J. Klimek, A. Walewski, Maria Curie Sklodowska Univ. (Poland) 
6990 OU Spectral-domain measurement of phase modal birefringence in highly birefringent fibers [6990-29]

P. Hlubina, D. Ciprian, J. Trojková, Technical Univ. Ostrava (Czech Republic)

6990 0V Dual-core photonic quasicrystal fiber with high negative dispersion [6990-30]

S. Kim, C.-S. Kee, J. Lee, Gwangju Institute of Science and Technology (South Korea);

C. G. Lee, Chosun Univ. (South Korea)

6990 0W Detection of methane at 1670-nm band with a hollow-core photonic bandgap fiber [6990-31]

A. M. Cubillas, M. Silva-Lopez, J. M. Lazaro, O. M. Conde, Univ. de Cantabria (Spain); M. N. Petrovich, Univ. of Southampton (United Kingdom); J. M. Lopez-Higuera, Univ. de Cantabria (Spain)

6990 0X A short overview of the most actual problems in the area of fiber bending and chromatic dispersion in photonic crystal fibers [6990-32]

M. Lucki, L. Bohac, J. Vodrazka, Czech Technical Univ. (Czech Republic)

$69900 Z$ Design of photonic crystal fibres with improved effective mode area and nearly zero ultra-flatted/negative chromatic dispersion [6990-34]

H. Ademgil, S. Haxha, Univ. of Kent (United Kingdom)

699011 Highly birefringent holey fibers with zero polarimetric sensitivity to temperature [6990-36]

T. Martynkien, Wroclaw Univ. of Technology (Poland) and Vrije Univ. Brussel (Belgium);

A. Anuszkiewicz, G. Statkiewicz, W. Urbanczyk, Wroclaw Univ. of Technology (Poland);

J. Wojcik, P. Mergo, M. Makara, Maria Curie-Skłodowska Univ. (Poland); T. Nasilowski,

H. Terryn, F. Berghmans, H. Thienpont, Vrije Univ. Brussel (Belgium)

Author Index 


\title{
Conference Committee
}

\author{
Symposium Chairs
}

Hugo Thienpont, Vrije Universiteit Brussel (Belgium)

Giancarlo C. Righini, Istituto di Fisica Applicata Nello Carrara, CNR (Italy)

Patrick P. Meyrueis, Université Lovis Pasteur (France)

Conference Chairs

Kyriacos Kalli, Cyprus University of Technology (Cyprus)

Waclaw Urbanczyk, Wroclaw University of Technology (Poland)

Program Committee

Hartmut Bartelt, Institut für Physikalische Hochtechnologie e.V.

(Germany)

Francis Berghmans, SCK • CEN (Belgium) and Vrije Universiteit Brussel

(Belgium)

Benjamin J. Eggleton, The University of Sydney (Australia)

Sébastien Février, Xlim, Université de Limoges (France)

Jiri Kanka, Institute of Radio Engineering and Electronics (Czech

Republic)

Jonathan C. Knight, University of Bath (United Kingdom)

Hanne Ludvigsen, Helsinki University of Technology (Finland)

Azizur B. M. Rahman, City University London (United Kingdom)

Karsten Rottwitt, Denmark University of Technology (Denmark)

Kay Schuster, Institut für Physikalische Hochtechnologie e.V. (Germany)

Dmitry V. Skryabin, University of Bath (United Kingdom)

Luc Thévénaz, École Polytechnique Fédérale de Lausanne (Switzerland)

David J. Webb, Aston University (United Kingdom)

\section{Session Chairs}

1 The NextGenPCF Project: Advances in Fundamentals Jonathan C. Knight, University of Bath (United Kingdom)

2 The NextGenPCF Project: Uses and Applications

Hartmut Bartelt, Institut für Physikalische Hochtechnologie e.V. (Germany)

3 Joint Session: Sensing Applications of PCF

Kyriacos Kalli, Cyprus University of Technology (Cyprus) 
$4 \quad$ Modelling and Numerical Analysis of PCF

Stavros Pissadakis, Foundation for Research and Technology - Hellas (Greece)

5 Characterisation and Applications of PCF

Gilles Renversez, Université Paul Cézanne (France)

$6 \quad$ Nonlinear and Active PCF I

Kay Schuster, Institut für Physikalische Hochtechnologie e.V. (Germany)

$7 \quad$ Nonlinear and Active PCF II

Sébastien Février, Xlim, Université de Limoges (France) 